\title{
Liolaemus pseudolemniscatus Lamborot and Ortiz, 1990 (Squamata: Liolaemidae): Distribution extension in Central Chile
}

\author{
Jaime Troncoso-Palacios \\ Universidad de Chile, Facultad de Medicina, Laboratorio de Fisiología y Biofísica. Casilla 70005. Santiago, Chile. \\ E-mail: jaimejpalacios@gmail.com
}

\begin{abstract}
Liolaemus pseudolemniscatus (Lamborot and Ortiz 1990) is a poorly known species. Two specimens were collected in "Cerro Provincia", central Chile, expanding in $136 \mathrm{~km}$ (straight line) its latitudinal distribution and in $800 \mathrm{~m}$ its altitudinal distribution. This record adds a new species of Liolaemus lizard for the "Región Metropolitana", Chile.
\end{abstract}

The genus Liolaemus (Wiegmann 1834) comprises a total of 223 species of wide distribution from the high Andes of central Perú to "Tierra del Fuego", and from sea level to more than $5000 \mathrm{~m}$ (Lobo et al. 2010). In Chile at least 88 species have been registered (Vidal et al. 2008).

Liolaemus pseudolemniscatus (Lamborot and Ortiz 1990) belongs to the subgenus Liolaemus and the nigromaculatus group (Lobo 2005). It is a small lizard of 45 to $52 \mathrm{~mm}$ snout-vent length with a thin and elongated body. It has a brown head with dark spots and an occipital gray band from occiput to base of tail.

The species is named for its resemblance to o ther species that inhabits central Chile, L. lemniscatus (Gravenhorst 1838). However, L. pseudolemniscatus has granular and rounded lateral neck scales, which are lanceolate, imbricate and carinate in L. lemniscatus (Figure 1), and the dorsal scales are less keeled in L. pseudolemniscatus. L. pseudolemniscatus presents a Y-shaped lateral neck fold (absent in L. lemniscatus), and an occipital grey band, which is yellowish-brown in L. lemniscatus (Figure 2). Moreover, L. pseudolemniscatus has a higher number of chromosomes $(2 n=44)$ than L. lemniscatus $(2 n=34)$ (Lamborot and Ortiz 1990).

Liolaemus pseudolemniscatus is distributed from the

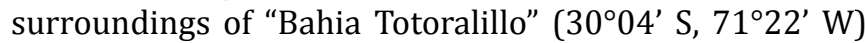
to "Hierro Viejo" (32 $16^{\prime} \mathrm{S}, 71^{\circ} 00^{\prime} \mathrm{W}$ ) in central Chile, between 25 and $1300 \mathrm{~m}$, (Lamborot and Ortiz 1990; Pincheira-Donoso and Núñez 2005). In addition, Mella (2005) mentioned a "probable record" from "El Arrayán" (3320' S, $70^{\circ} 28^{\prime} \mathrm{W}$ ), located $120 \mathrm{~km}$ south (straight line) from the known distribution limit and $2000 \mathrm{~m}$ above sea level. The species is not included in the IUCN Red List of Threatened Species (IUCN 2010).

During a field trip to "Cerro Provincia" mountain (3323'S, 70²7' W), several specimens of $L$. pseudolemniscatus were found between 1600 and 2100 $\mathrm{m}$. This mountain is located $135 \mathrm{~km}$ south (straight line) from the known distribution limit of this species (Figure

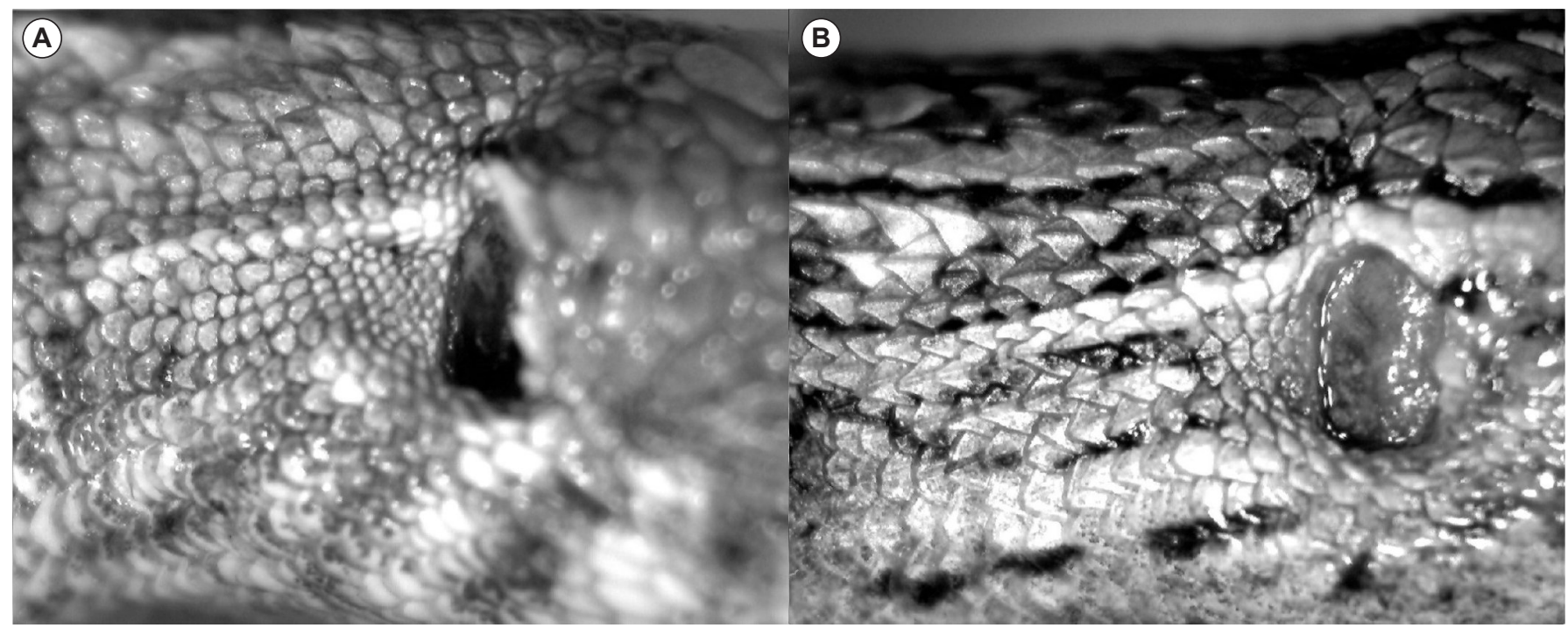

FIGURE 1. Lateral neck scales in (A) Liolaemus pseudolemniscatus (Re-0031) and (B) Liolaemus lemniscatus (Re-0052). 
3). Two individuals were collected (male and female) and deposited in the "Colección de Flora y Fauna Prof. Patricio Sánchez Reyes, Universidad Católica de Chile”, (SSUC Re0030-31). Morphological measurements were taken with a digital vernier calliper of precision $0.02 \mathrm{~mm}$ (Table 1). The male presented three precloacal pores. Several specimens of L. lemniscatus were examined for comparison (SSUC 0052, MRC 0210-219).

In repeated visits to the mountain, new individuals were observed in winter, spring and summer, during sunny days, in bushes (Adesmia sp., Ephedra chilensis, Proustia pungens) or in small rocks. It was found in sympatry with L. fuscus, L. monticola and L. nitidus. This record expands the southern limit of this species in $136 \mathrm{~km}$ and the altitudinal distribution limit in $800 \mathrm{~m}$. The unconfirmed record from "El Arrayán" (Mella 2005) is consistent with this finding. With this record a new species of Liolaemus for the "Región Metropolitana" in Chile is added.

TABLE 1. Morphological measurements (in $\mathrm{mm}$ ) for collected specimens of Liolaemus pseudolemniscatus. SVL: snount-vent length, HL: head length, HW: Head width, AGD: Axilla-groin distance.

\begin{tabular}{lcccc}
\hline & SVL & HL & HW & AGD \\
\hline Male (Re-0030) & 54.2 & 14.2 & 8.9 & 24.4 \\
Female (Re-0031) & 47.1 & 11.4 & 6.7 & 21.9 \\
\hline
\end{tabular}

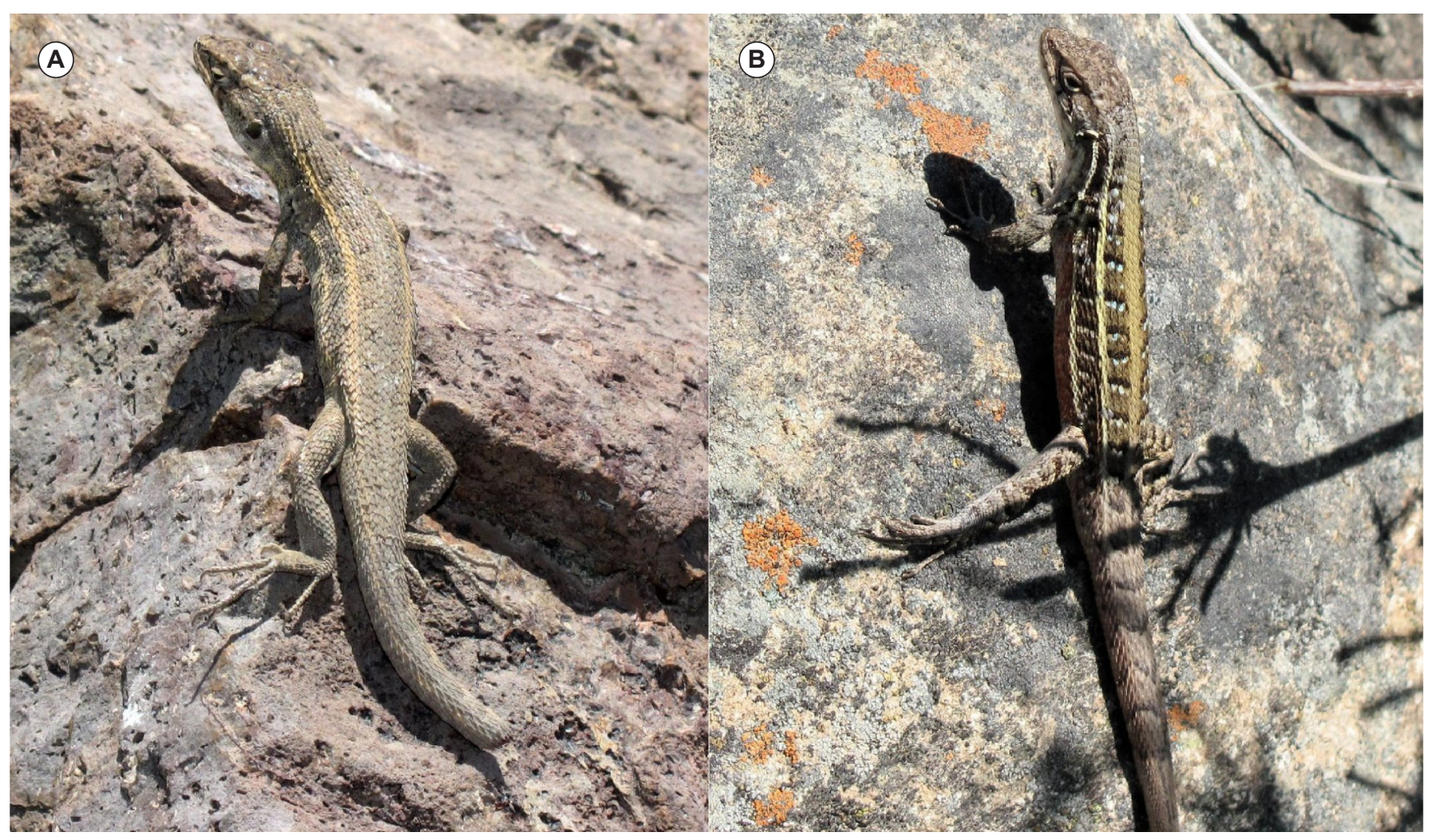

FIGURE 2. View of dorsal pattern coloration in life. (A) Adult male of Liolaemus pseudolemniscatus (Re-0030). (B) Adult male of Liolaemus lemniscatus from Machalí.

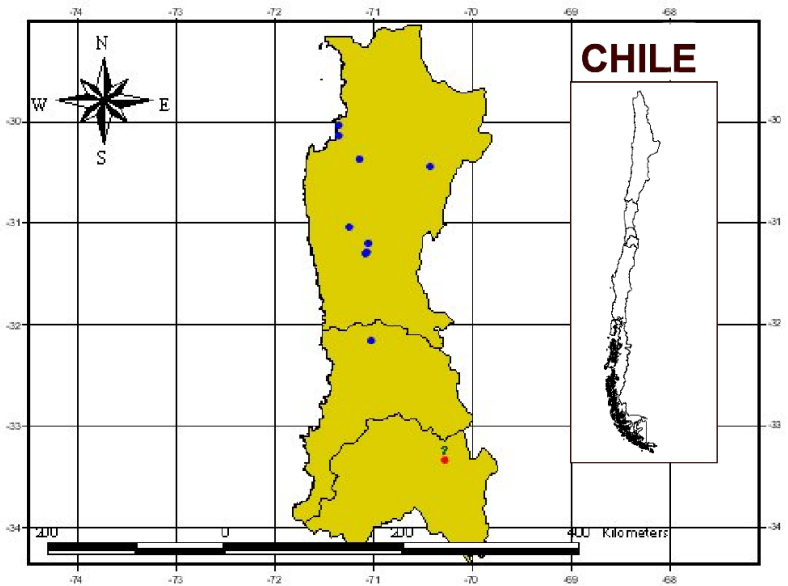

FigurE 3. Distribution of Liolaemus pseudolemniscatus. The administrative boundaries of the three regions of central Chile where the species is located (from north to south: Coquimbo, Valparaíso and Metropolitana) are shown. The blue points show previously known localities (Lamborot and Ortiz 1990; Pincheira-Donoso and Núñez 2005), the green question mark shows a "probable record" (Mella 2005) and the red point shows the new record reported here.
ACKNOWLEDGMENTS: Thanks to C. Garín and P. Zavala for allowing access to the SSUC Collection. To J.F. Troncoso for allowing access to the MRC (Museo Regional de Concepción) collection. To M. Penna for his support and to F. Urra for reviewing the manuscript.

\section{Literature Cited}

Donoso-Barros, R. 1966. Reptiles de Chile. Santiago: Ediciones de la Universidad de Chile. cxliv +458 p.

Gravenhorst, J.L.C. 1838. Beiträge zur genauern Kenntniss einiger Eidechsengattungen. Nova Acta Academiae Caesarae Leopoldina Carolinae Germaninicae Naturae Curisorum 18 (2): 712-784.

IUCN 2010. IUCN Red List of Threatened Species. Version 2010.4. Electronic Database accessible at http://www.iucnredlist.org. Captured on 11 April 2011.

Lamborot, M. and J.C. Ortiz. 1990. Liolaemus pseudolemniscatus, una nueva especie de lagarto del Norte Chico de Chile (Sauria: Tropiduridae). Gayana: Zoología 54: 135-142.

Lobo, F. 2005. Las relaciones filogenéticas dentro del grupo chiliensis (Iguania: Liolaemidae: Liolaemus): sumando nuevos caracteres y taxones. Acta Zoológica Lilloana 49: 65-87.

Lobo, F., R.E. Espinoza and S. Quinteros. 2010. A critical review and systematic discussion of recent classification proposals for liolaemid lizards. Zootaxa 2549: 1-30.

Mella, J.E. 2005. Guía de campo reptiles de Chile: Zona Central. Peñaloza, A.P.G., F. Novoa and M. Contreras (ed.). Santiago: Ediciones del Centro de Ecología Aplicada Ltda. 147p.

Pincheira-Donoso, D. and H. Núñez. 2005. Las especies chilenas del género Liolaemus Wiegmann. 1834. (Iguania: Tropiduridae: Liolaeminae). 
Taxonomía, sistemática y evolución. Publicación Ocasional, Museo Nacional de Historia Natural (Chile) 59: 1-486.

Vidal, M.A., M. Iturra-Cid and J.C. Ortiz. 2008. Clasificación de anfibios y reptiles; p. 79-106 In M.A. Vidal and A. Labra (ed.). Herpetología de Chile. Santiago: Science Verlag.

Wiegmann, A.F.A. 1834. Herpetologica Mexicana seu descriptio amphibiorum Novae Hispaniae quae itineribus comitis de Sack, Ferdinandi Deppe et Chr. Guil. Schiede in Museum Zoologicum Berolinense pervenerunt. Pars prima, Saurorum species amplectens, adiecto Systematis Saurorum Prodromo, additisque multis in hunc amphibiorum ordinem observationibus. Berlin: Lüderitz. vi + 54 p.
RECEIVED: June 2011

LAST REVISED: October 2011

ACCEPTED: October 2011

Published online: December 2011

EDITORIAL RESPONSIBILITY: Omar Torres-Carvajal 